\title{
Thyroid abnormalities in term infants with fungal sepsis
}

\author{
Maria Helena Baptista Nunes da Silla ${ }^{1}$, Maria Cristina Korbage de Araujo², Edna Maria de Albuquerque Diniz ${ }^{3}$, \\ Maria Esther Jurfest Rivero Ceccon ${ }^{4}$, Werther Brunow de Carvalho ${ }^{5 *}$

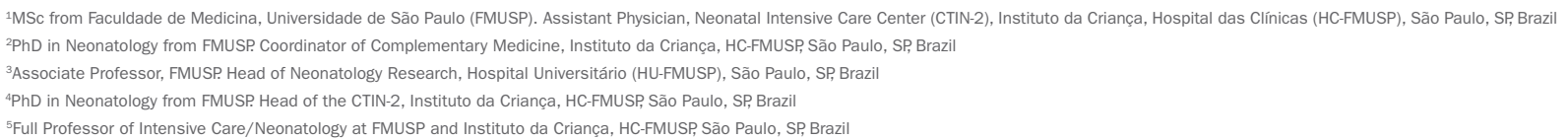

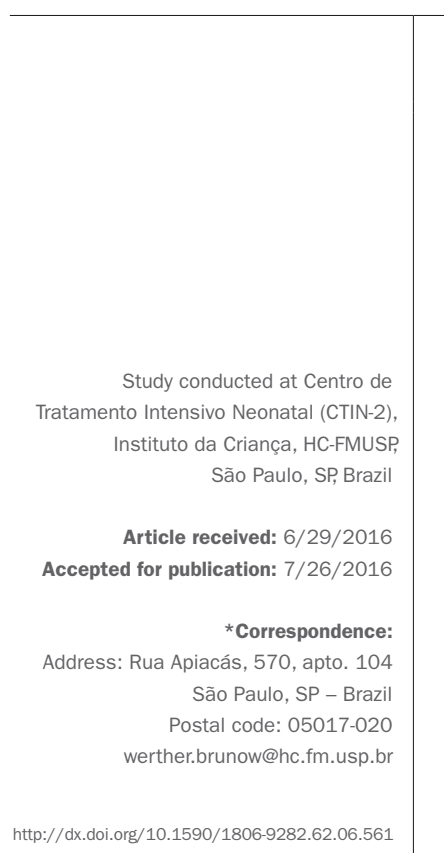

\section{SUMmARY}

Objective: To describe thyroid alterations in term newborns (TNB) with fungal sepsis during NICU hospitalization.

Method: The study included six TNB that during the clinical and laboratory manifestations of sepsis with positive cultures for fungus showed changes in thyroid hormones, called low T3 syndrome and low T3-T4 syndrome. TNB that could present hormonal changes caused by disease as those born to mothers with thyroid disease, or who had perinatal asphyxia and major surgeries were excluded.

Results: Of six TNB with fungal sepsis, five had positive culture for Candida albicans and one had positive culture for Candida tropicalis. Low T3 syndrome was observed in two TNB (50\%), while T3-T4 syndrome was observed in other two (100\%). The four children progressed to septic shock.

Conclusion: Fungal sepsis is becoming more common among newborns admitted to NICU. Thyroid insufficiency could be a marker of disease severity with possible need for hormone supplementation.

Keywords: full-term newborn, thyroidal hormone, fungal sepsis, septic shock.

\section{INTRODUCTION}

Late-onset neonatal sepsis is directly related to postnatal factors and the multiple invasive procedures to which these infants are submitted at the neonatal intensive care unit (NICU). These procedures include tracheal intubation, percutaneous catheters, venipuncture, and parenteral nutrition. Hospital microorganisms are the main causative agents of sepsis, including bacteria and fungi, ${ }^{1-3}$ and can be transmitted horizontally through the staff and from the professionals' hands.

Sepsis may affect various tissues and modify the action of certain enzymes, including those responsible for the formation of thyroid hormones in peripheral tissues, causing the so-called non-thyroidal illness syndrome (NTIS), which is characterized by the presence of abnormalities in thyroid hormone serum levels, but without the classic thyroid disease that can affect adults, children and even infants..$^{4-8}$ NTIS has been used as an interesting parameter of severity, since it has been verified that more severe patients have more prolonged alterations and a later recovery, and that the prognosis in adults is poor, and may even lead to death. ${ }^{9-12}$ However, there are still no reports of there being a worse prognosis in infants, let alone those presenting fungal sepsis.

It is believed that most episodes of candidemia are of endogenous origin, through the translocation of the pathogen via gastrointestinal tract mucosa, where colonization by this fungus occurs in up to $70 \%$ of the normal population. ${ }^{13}$ Any variable that causes an imbalance in the microbiota or harm to the gastrointestinal mucosa can be a facilitating agent for the translocation of Candida ssp. from the intestinal lumen to the mesenteric capillaries. ${ }^{14}$ The second most common cause of bloodstream infection in pediatric and neonatal patients admitted to intensive care units in the USA, Europe, and Latin America is fungal infections, especially by Candida spp. ${ }^{13-16}$ In recent years, an increase in infections caused by other species of Candida non-albicans, such as Candida tropicalis, Candida glabrata, Candida krusei, Candida lusitaniae and Candida guilliermondii, has been noted. Multicenter studies conducted in Brazil have also confirmed the prevalence of species of Candida albicans and non-albicans (C. tropicalis and parapsilosis). ${ }^{16-18}$ 


\section{THYROID HORMONES IN THE NEWBORN}

Soon after umbilical cord clamping, term infants present high T3 values, reaching 3 to 6 times the fetal serum levels, concomitant with an abrupt increase in thyroid-stimulating hormone (TSH) and catecholamines in response to the temperature differences between the intra- and extra-uterine environments, and the stress of labor. $\mathrm{T} 4$ also rises 30 minutes after delivery, with serum levels that can reach 80 to $100 \mathrm{mU} / \mathrm{L}$. All of these hormones decrease within 24 hours, remaining at higher levels than those of the cord blood for 2 to 3 days. ${ }^{4-9}$ In the same manner as the thyroid hormones, there is a rapid increase in cortisol in term infants at birth, which can reach $20 \mu \mathrm{g} / \mathrm{dL}$. This hormone stimulates the increase in serum $\mathrm{T} 3$, which is essential for activation of type 1 deiodinase (D1) enzyme between 4 and 6 hours after birth, and very low levels of reverse T3. ${ }^{19-28}$

Currently, four stages of NTIS are recognized in adults and children, known as low T3 syndrome, low T3-T4 syndrome, high $\mathrm{T} 4$ syndrome, and mixed syndromes. ${ }^{4-10,20-28}$

\section{Low T3 syndrome}

This is characterized by low serum levels of T3, normal or slightly increased TSH, and normal free T4 and T4. The level of reverse T3 may be normal or increased. This change is due to inhibition of the activity of the D1 enzyme, which is responsible for both peripheral degradation of $\mathrm{T} 4$ to $\mathrm{T} 3$ as well as lower clearance of reverse $\mathrm{T} 3{ }^{6-12}$ The decline in $\mathrm{T} 3 \mathrm{lev}$ els appears to occur a few hours after the onset of sepsis. ${ }^{6,10,23-28}$ Recovery occurs in parallel with the improvement of the underlying disease. ${ }^{24-28}$ Low T3 syndrome is the most frequent NTIS abnormality in adults and children. Evidence indicates that low $\mathrm{T} 3$ syndrome may be an adaptive response to stress, without association with worse prognoses or increased mortality. ${ }^{22-28}$ For Papanicolaou, low T3 syndrome corresponds to the first stage of non-thyroidal illness syndrome. ${ }^{6}$

\section{Low T3-T4 syndrome}

This is characterized by the presence of low T4 and T3, with low TSH being frequent, alongside normal or high reverse T3. This situation has been observed in seriously ill and dying adults and children. Initially, this type of NTIS was explained by the presence of a probable inhibitor of $\mathrm{T} 4$ binding to thyroglobulin in the serum. It is currently believed that a mechanism occurs in this type of NTIS related to the effects of cytokines in the hypothalamic-pituitary axis, associated with reduced peripheral T4 action..$^{4-12,19-28}$ The response of TSH to thyrotropin-releasing hormone (TRH) seems to be reduced in patients in critical clinical condition. There is evidence that in certain periods of severe disease there may be genuine central and transient hy- pothyroidism, in which there is not a nighttime peak in TSH, as well as evidence of changes in the glycosylation process regulated by TRH. ${ }^{4,9,19-28}$ Studies have also suggested reduced T4 action in tissue levels, varying from tissue to tissue, through the demonstration of low serum levels of angiotensin-converting enzyme, which in turn is stimulated by thyroid hormones. ${ }^{5,7,20-28}$ In the recovery phase, there may be a temporary increase in TSH..$^{20-28}$

\section{High T4 syndrome}

This is characterized by high serum levels of T4, normal or slightly increased T3 and high reverse T3. Free T3 and free T4 are usually normal or low., ${ }^{5,27}$ The prevalence of this syndrome is usually low. In the initial phase, the decrease in the peripheral metabolism of $\mathrm{T} 4$ through inactivation of the D1 enzyme may cause increased rates of this hormone; however, the situation is reversed in a few hours, causing a decline in T4 levels. ${ }^{4-6,10,19-28}$

\section{Mixed syndromes}

In mixed syndromes, a combination of the abnormalities described above can be found. ${ }^{4-6,10,19-28}$

When completing our master's thesis, we noted thyroid abnormalities in infants with bacterial sepsis, and in the present study we also found six infants with fungal infection. As we found no published cases in the literature, we decided to write this article in order to present the changes in thyroid hormones in fungal sepsis.

The study was conducted with the newborns whose parents or legal guardians signed the informed consent form, after approval of the research project by the Ethics Committee at Instituto da Criança and the HC-FMUSP Ethics and Research Committee, with registration at the National Ethics and Research Commission under number 0329.0.015.000-03.

The infants with fungal sepsis made up $17.9 \%$ of the total sample (six infants). These infants had laboratory manifestations of sepsis, as well as positive blood cultures for fungi in five of them and one positive urine culture, as well as clinical and radiological signs of fungal sepsis.

Infants with severe asphyxia, surgical and cardiac malformations, major surgeries, infants born to mothers with thyroid disease, with congenital infections, and intrauterine growth delay were excluded because these conditions could alter their hormone levels.

The blood samples to test the hormone levels were collected from peripheral veins at the same time as routine tests for sepsis (blood count, C-reactive protein and blood culture). One extra milliliter of blood was taken 
from the selected patients in order to measure total T4, free T4, T3, reverse T3 and TSH levels. ${ }^{1-3,29-31}$

NTIS was considered present when abnormalities were found in the serum levels of thyroid hormones, such as the presence of low T3, low T3-T4, high T4, and mixed levels.

Five of the infants with fungal sepsis presented positive blood cultures, with four for Candida albicans and one for Candida tropicallis. One infant presented urine culture positive for Candida albicans.
Low T3 syndrome was observed in four infants (66.7\%) and low T3-T4 in two infants (33.3\%). Two infants with low T3 syndrome (50\%) had septic shock and two with low T3-T4 syndrome also progressed with septic shock (100\%).

Table 1 shows a statistically significant difference in relation to the blood count and its differentials and Creactive protein.

Table 2 describes the clinical and laboratory variables of infants according to the duration of fungal sepsis dur-

\begin{tabular}{|c|c|c|c|c|c|c|c|}
\hline Data & Group & Median & Standard deviation & Mean & Standard error & Range & $\mathbf{P}$ \\
\hline \multirow[t]{2}{*}{ Weight (g) } & A & 2825 & 670.6 & 2947.5 & 335.3 & $1905-3500$ & \multirow[t]{2}{*}{0.10} \\
\hline & B & 2930 & 1301.1 & 2930 & 920.0 & $2010-3850$ & \\
\hline \multirow[t]{2}{*}{ Temperature } & A & 37.72 & 1.35 & 38.30 & 0.67 & $35.7-38.5$ & \multirow[t]{2}{*}{1.0} \\
\hline & B & 36.95 & 2.19 & 36.95 & 1.55 & $35.4-38.5$ & \\
\hline \multirow[t]{2}{*}{ Heart rate } & A & 169.75 & 21.48 & 176.5 & 10.74 & $140-186$ & \multirow[t]{2}{*}{0.16} \\
\hline & B & 192.5 & 14.85 & 192.5 & 10.50 & $182-203$ & \\
\hline \multirow{2}{*}{$\begin{array}{l}\text { Respiratory } \\
\text { rate }\end{array}$} & A & 67.50 & 13.30 & 67 & 6.65 & $52-84$ & \multirow[t]{2}{*}{0.70} \\
\hline & B & 62.00 & 25.46 & 62 & 18.00 & $44-80$ & \\
\hline \multirow[t]{2}{*}{ Leukocyte } & A & 21215 & 11477.02 & 25445 & 5738.51 & $4270-29700$ & \multirow[t]{2}{*}{0.0001} \\
\hline & B & 14655 & 3613.32 & 14655 & 2555.00 & $12100-17210$ & \\
\hline \multirow{2}{*}{$\begin{array}{l}\text { Immature } \\
<10 \%\end{array}$} & A & 0.28 & 0.21 & 0.18 & 0.10 & $0.15-0.61$ & \multirow[t]{2}{*}{0.0005} \\
\hline & $\mathrm{B}$ & 0.27 & 0.17 & 0.27 & 0.12 & $0.15-0.4$ & \\
\hline \multirow[t]{2}{*}{ INR } & $\mathrm{A}$ & 0.19 & 0.11 & 0.14 & 0.05 & $0.12-0.37$ & \multirow[t]{2}{*}{0.0001} \\
\hline & B & 0.20 & 0.10 & 0.20 & 0.07 & $0.13-0.28$ & \\
\hline \multirow{2}{*}{$\begin{array}{l}\text { C-reactive } \\
\text { protein }\end{array}$} & $A$ & 75.75 & 81.95 & 51.8 & 40.97 & $5.4-194$ & \multirow[t]{2}{*}{0.0044} \\
\hline & B & 189.55 & 30.61 & 189.55 & 21.65 & $167.9-211.2$ & \\
\hline
\end{tabular}

A - Low T3 syndrome; B - Low T3-T4 syndrome; INR: neutrophilic index of Rodwel score.

TABLE 2 Clinical and laboratory variables of infants according to the duration of fungal sepsis during convalescence.

\begin{tabular}{|c|c|c|c|c|c|c|c|}
\hline Data & Group & Median & Standard deviation & Mean & Standard error & Range & $\mathbf{p}$ \\
\hline \multirow[t]{2}{*}{ Weight (g) } & $A$ & 2837.50 & 666.96 & 2947.5 & 333.48 & $1935-3520$ & \multirow[t]{2}{*}{0.0041} \\
\hline & B & 2767.50 & 783.75 & 2602.5 & 312.15 & $1855-4125$ & \\
\hline \multirow[t]{2}{*}{ Temperature } & A & 37.52 & 0.69 & 37.5 & 0.34 & $36.8-38.3$ & \multirow[t]{2}{*}{1.0} \\
\hline & B & 37.05 & 0.75 & 37.0 & 0.26 & $36-37.4$ & \\
\hline \multirow[t]{2}{*}{ Heart rate } & A & 164.50 & 3.42 & 165 & 1.71 & $160-168$ & \multirow[t]{2}{*}{0.51} \\
\hline & B & 150.63 & 8.43 & 148 & 2.98 & $142-160$ & \\
\hline \multirow{2}{*}{$\begin{array}{l}\text { Respiratory } \\
\text { rate }\end{array}$} & $A$ & 63 & 15.10 & 60 & 7.55 & $48-84$ & \multirow[t]{2}{*}{0.66} \\
\hline & B & 65.3 & 12.43 & 67 & 4.40 & $48-88$ & \\
\hline \multirow[t]{2}{*}{ Leukocyte } & A & 16405.00 & 9974.04 & 18500 & 4987.02 & $2520-26100$ & \multirow[t]{2}{*}{0.0001} \\
\hline & B & 17242.50 & 16956.61 & 8555 & 5995.07 & $2690-42490$ & \\
\hline \multirow{2}{*}{$\begin{array}{l}\text { Immature } \\
<10 \%\end{array}$} & A & 0.077 & 0.14 & 0.009 & 0.07 & $0-0.29$ & \multirow[t]{2}{*}{0.32} \\
\hline & B & 0.031 & 0.048 & 0 & 0.17 & $0-0.13$ & \\
\hline \multirow[t]{2}{*}{ INR } & A & 0.07 & 0.13 & 0.008 & 0.06 & $0-0.28$ & \multirow[t]{2}{*}{0.56} \\
\hline & B & 0.02 & 0.04 & 0 & 0.014 & $0-0.11$ & \\
\hline
\end{tabular}


TABLE 2 (Cont.) Clinical and laboratory variables of infants according to the duration of fungal sepsis during

convalescence.

\begin{tabular}{llllllll} 
Data & Group & Median & Standard deviation & Mean & Standard error & Range & P \\
\hline C-reactive & $\mathrm{A}$ & 69.12 & 58.12 & 71.35 & 29.35 & $7.4-126.4$ \\
nyotein & $\mathrm{B}$ & 92.87 & 58.48 & 111.45 & 20.67 & $3.2-159.9$
\end{tabular}

A - Low T3 syndrome; B - Low T3-T4 syndrome; INR: neutrophilic index of Rodwel score.

ing convalescence. Statistically significant differences were noted between the two groups in relation to weight, blood count and C-reactive protein. In Table 3 , the variables related to recovery had no significant changes, except for the case of laboratory parameters:

- A - Low T3 syndrome: one case continued high;
- B - Low T3-T4 syndrome: in one case the patient was re-infected and underwent surgery.

Tables 4 and 5 show the arithmetic means of the thyroid hormones and TSH according to the evolution of sepsis in the infants with low T3 and low T3-T4 syndromes, respectively.

\section{TABLE 3 Clinical and laboratory variables of infants according to the duration of fungal sepsis upon recovery.}

\begin{tabular}{|c|c|c|c|c|c|c|c|}
\hline Data & Group & Median & Standard deviation & Mean & Standard error & Range & $\mathbf{P}$ \\
\hline \multirow[t]{2}{*}{ Weight (g) } & A & 2892.50 & 719.40 & 2910 & 359.70 & $2015-3735$ & \multirow[t]{2}{*}{0.22} \\
\hline & B & 3140 & 1400.07 & 3140 & 990.00 & $2150-4130$ & \\
\hline \multirow[t]{2}{*}{ Temperature } & $A$ & 36.65 & 0.19 & 36.6 & 0.09 & $36.5-36.9$ & \multirow[t]{2}{*}{0.86} \\
\hline & B & 37.15 & 0.91 & 37.15 & 0.65 & $36.5-37.8$ & \\
\hline \multirow[t]{2}{*}{ Heart rate } & A & 140 & 14.1 & 135 & 7.07 & $130-160$ & \multirow[t]{2}{*}{0.52} \\
\hline & B & 143 & 9.90 & 143 & 7.00 & $136-150$ & \\
\hline \multirow[t]{2}{*}{ Respiratory rate } & A & 35 & 3.46 & 34 & 1.76 & $32-40$ & \multirow[t]{2}{*}{0.39} \\
\hline & B & 41.5 & 8.5 & 41.5 & 12.02 & $33-50$ & \\
\hline \multirow[t]{2}{*}{ Leukocyte } & A & 10335 & 3081.92 & 10620 & 1540.96 & 7100-13000 & \multirow[t]{2}{*}{0.0001} \\
\hline & B & 11910 & 438.41 & 11910 & 310.0 & $11600-12220$ & \\
\hline \multirow[t]{2}{*}{ Immature $<10 \%$} & $A$ & 0.004 & 0.009 & 0 & 0.004 & $0-0.019$ & \multirow[t]{2}{*}{0.56} \\
\hline & B & 0.00 & 0.00 & 0 & 0.0 & 0 & \\
\hline \multirow[t]{2}{*}{ INR } & A & 0.004 & 0.009 & 0 & 0.004 & $0-0.018$ & \multirow[t]{2}{*}{0.0001} \\
\hline & B & 0.00 & 0.00 & 0 & 2 & 0 & \\
\hline \multirow[t]{2}{*}{ C-reactive protein } & A & 10.3 & 14.3 & 3.2 & 7.15 & $3.2-31.9$ & \multirow[t]{2}{*}{0.01} \\
\hline & B & 62.2 & 83.43 & 62.2 & 59.0 & $3.2-121.2$ & \\
\hline
\end{tabular}

A - Low T3 syndrome; B - Low T3-T4 syndrome; INR: neutrophilic index of Rodwel score.

TABLE 4 Arithmetic means of the thyroid hormones and TSH according to the evolution of sepsis in the infants with low T3 syndrome.

\begin{tabular}{|c|c|c|c|c|}
\hline \multirow{2}{*}{$\begin{array}{l}\text { Variable } \\
\text { Hormone }\end{array}$} & \multicolumn{4}{|l|}{ Progression } \\
\hline & \multicolumn{4}{|c|}{ Median \pm standard deviation } \\
\hline Thyroid hormones & Admission ( a ) & Convalescence ( b ) & Cure (c) & $\mathbf{P}$ \\
\hline \multirow[t]{3}{*}{ T3 } & $59.97 \pm 36.27$ & $101.3 \pm 77.98$ & $206.25 \pm 39.98$ & $a \times b=0.80$ \\
\hline & & & & $b \times c=0.002$ \\
\hline & & & & $\mathrm{a} \times \mathrm{c}=0.001$ \\
\hline \multirow[t]{3}{*}{ T4 } & $7.80 \pm 2.16$ & $12.99 \pm 6.29$ & $12.52 \pm 2.65$ & $a \times b=1.0$ \\
\hline & & & & $b \times c=1.0$ \\
\hline & & & & $a \times c=1.0$ \\
\hline
\end{tabular}


TABLE 4 (Cont.) Arithmetic means of the thyroid hormones and TSH according to the evolution of sepsis in the infants with low T3 syndrome.

\begin{tabular}{|c|c|c|c|c|}
\hline \multirow{2}{*}{$\begin{array}{l}\text { Variable } \\
\text { Hormone } \\
\text { Thyroid hormones }\end{array}$} & \multicolumn{4}{|l|}{ Progression } \\
\hline & Admission ( a ) & Convalescence ( b ) & Cure (c) & $\mathbf{p}$ \\
\hline \multirow[t]{4}{*}{ Free T4 } & $1.33 \pm 0.89$ & $1.70 \pm 0.43$ & $1.55 \pm 0.31$ & $a \times b=0.58$ \\
\hline & & & & $b \times c=0.39$ \\
\hline & & & & $\mathrm{a} \times \mathrm{c}=0.77$ \\
\hline & & & & $a \times c>0.05$ \\
\hline \multirow[t]{3}{*}{ Reverse T3 } & $99.96 \pm 79.04$ & $95.27 \pm 27.88$ & $91.45 \pm 9.5$ & $a \times b=0.30$ \\
\hline & & & & $b \times c=0.075$ \\
\hline & & & & $a \times c=0.009$ \\
\hline \multirow[t]{3}{*}{ TSH } & $2.16 \pm 2.30$ & $3.88 \pm 2.05$ & $1.77 \pm 0.74$ & $a \times b=1.0$ \\
\hline & & & & $b \times c=1.0$ \\
\hline & & & & $\mathrm{a} \times \mathrm{c}=1.00$ \\
\hline
\end{tabular}

TSH: thyroid-stimulating hormone.

TABLE 5 Arithmetic means of the thyroid hormones and TSH according to the evolution of sepsis in the infants with low T3-T4 syndrome.

\begin{tabular}{|c|c|c|c|c|}
\hline \multirow{3}{*}{$\begin{array}{l}\text { Variable } \\
\text { Hormone } \\
\text { Thyroid hormones }\end{array}$} & \multicolumn{4}{|l|}{ Progression } \\
\hline & \multicolumn{4}{|c|}{ Median \pm standard deviation } \\
\hline & Admission ( a ) & Convalescence ( b ) & Cure (c ) & $\mathbf{p}$ \\
\hline \multirow[t]{3}{*}{ T3 } & $46.5 \pm 3.5$ & $73.58 \pm 44.9$ & $76.50 \pm 108.19$ & $a \times b=0.80$ \\
\hline & & & & $\mathrm{b} \times \mathrm{c}=0.0020$ \\
\hline & & & & $\mathrm{a} \times \mathrm{c}=0.0010$ \\
\hline \multirow[t]{3}{*}{ T4 } & $3.8 \pm 1.57$ & $7.78 \pm 3.9$ & $5.5 \pm 7.78$ & $a \times b=1.0$ \\
\hline & & & & $b \times c=1.0$ \\
\hline & & & & $\mathrm{a} \times \mathrm{c}=1.0$ \\
\hline \multirow[t]{4}{*}{ Free T4 } & $1.28 \pm 0.30$ & $1.16 \pm 0.55$ & $0.88 \pm 1.2$ & $a \times b=0.58$ \\
\hline & & & & $b \times c=0.39$ \\
\hline & & & & $\mathrm{a} \times \mathrm{c}=0.77$ \\
\hline & & & & $\mathrm{a} \times \mathrm{c}>0.05$ \\
\hline \multirow[t]{3}{*}{ Reverse T3 } & $59.0 \pm 83.44$ & $70.15 \pm 16.05$ & $33.9 \pm 47.9$ & $\mathrm{a} \times \mathrm{b}=0.30$ \\
\hline & & & & $b \times c=0.075$ \\
\hline & & & & $\mathrm{a} \times \mathrm{c}=0.009$ \\
\hline \multirow[t]{3}{*}{ TSH } & $0.74 \pm 1.0$ & $2.82 \pm 2.21$ & $1.7 \pm 2.4$ & $a \times b=1.0$ \\
\hline & & & & $b \times c=1.0$ \\
\hline & & & & $\mathrm{a} \times \mathrm{c}=1.00$ \\
\hline
\end{tabular}

TSH: thyroid-stimulating hormone.

\section{Discussion}

Sepsis due to fungi in the neonatal period occurs in infants admitted to the ICU for long periods of time, especially affecting infants with a birth weight $<1500 \mathrm{~g}$. We emphasize that this study only included term infants, but even so we noted six infants presenting the condition. In Brazil, a multicenter study conducted in the 1990s by Colombo et al. in the cities of São Paulo and Rio de Janeiro observed 145 patients, including adults and children, with positive blood culture for Candida: albicans (37\%), parapsilosis (25\%), tropicalis (24\%), rugosa (5\%), and glabrata (4\%). This publication mentions that 28 of these infections were in children (19.7\%). ${ }^{32}$ Its results in infants at that time are similar to our study population.

In the city of São Paulo, a study of four tertiary hospitals by Matta et al. analyzed all of the positive blood 
cultures for fungi from all of the patients admitted to these services (adults and children) in two different periods (1995-1999 and 2000-2003) and found that Candida albicans was higher in both periods, and in the second period there were more species of Candida. ${ }^{33}$

In 2009, another study was also conducted in our country by Godim et al. at a neonatal intensive care unit with ten beds at a Tertiary University Hospital, in the city of Uberlândia, regardless of the gestational age, found 19 cases of candidemia, with Candida albicans also being the most common, similar to all of the studies cited to date [nine cases of Candida albicans (47.9\%), five of Candida krusei (26.3\%), two of Candida parapsilosis (10.5\%), two of Candida glabrata (10.5\%), and one of Candida tropicalis (5.3\%)]. ${ }^{34}$ In Latin America, Nucci et al. found 89 infants with candidemia, and $27 \%$ with C. parapsilosis. ${ }^{16}$

In a study carried out in the United States in 2000 by Zaoutis et al., which analyzed data from adult and pediatric populations admitted to tertiary hospitals, the fourth leading cause of infection was fungi, present in 1,118 children aged 0 to 7 years, that is, $43 \%$ of the total sample. ${ }^{35}$ On the other hand, in a study of 24 infants with a gestational age between 24 and 40 weeks, Spanish authors found seven cases of Candida albicans (29.2\%) and 17 cases of Candida non-albicans, 16 cases of which were Candida parapsilosis $(66.7 \%)$ and one case of Candida glabrata (4.2\%). The mortality rate of these children was around $21 \%{ }^{36}$ In our case series we also observed the presence of Candida non-albicans, a finding that is becoming increasingly common. In our study we had one case of Candida parapsilosis, and none of the six infants died, despite four of them having presented septic shock. The Spanish study reports $21 \%$ mortality.

In our study, even though the sample comprised newborns, we also found a similar rate, with a predominance of Candida albicans (66.8\%) and Candida tropicalis (16.6\%), as shown in other studies described above.

In the past, the majority of fungal infections in the population were labeled as Candida ssp., although the vast majority was Candida albicans. From the 1990s onwards, there was a significant increase in the number of infections caused by Candida non-albicans, such as Candida parapsilosis and other types of Candida in the global population. ${ }^{30-37}$

Low T3-T4 syndrome described in critically ill adults and children is linked to poor prognosis and greater severity of the disease. In our study, all of the infants with fungal sepsis survived, so it is not possible to relate this type of syndrome with poor prognosis. However, it was possible to relate the greater severity of the disease, as two of the six infants with low T3 (50\%) and two infants with low T3T4 (100\%) had shock, demonstrating that it would be pos- sible to use these hormones as markers of severity, even with a small case series such as ours. Another possibility would be the treatment of these changes in children with septic shock, where despite our patients not having progressed to death, the cases remained extremely severe and had prolonged hospitalization. More studies and larger case series are necessary to prove this. Nevertheless, there are studies on older septic patients in which thyroid hormones were administered, leading to clinical improvement.

\section{Conclusion}

Fungal sepsis is becoming more common among newborns admitted to the NICU and thyroid insufficiency, with the variables described, could be a marker of disease severity with possible need for hormone supplementation.

\section{Resumo}

Alterações tireoidianas no recém-nascido de termo com sepse fúngica

Objetivo: descrever as alterações tireoidianas em recém-nascidos de termo (RNT) que apresentaram sepse fúngica durante internação na UTI neonatal.

Método: foram incluídos seis RNT que, durante as manifestações clínicas e laboratoriais de sepse, com culturas positivas para fungo, apresentaram alterações dos hormônios tireoidianos, denominadas síndrome do T3 baixo e síndrome do T3 e T4 baixo. Foram excluídos RNT que apresentaram alteração hormonal por doença, como RNT filhos de mães com doença tireoidiana, asfixia perinatal e cirurgias de grande porte.

Resultados: dos seis RNT com sepse fúngica, cinco apresentavam cultura positiva para Candida albicans e um para C. tropicalis. A síndrome do T3 baixo foi observada em duas crianças (50\%) e a do T3 e T4 baixo em dois RN (100\%). As quatro crianças evoluíram com choque séptico.

Conclusão: a sepse fúngica é cada vez mais frequente nos recém-nascidos internados em UTI neonatal. A insuficiência tireoidiana pode vir a ser marcadora de gravidade da doença, e a suplementação hormonal pode ser necessária.

Palavras-chave: recém-nascido de termo, hormônio tireoidiano, sepse fúngica, choque séptico.

\section{References}

1. Silveira RC, Procianoy RS. Uma revisão atual sobre sepse neonatal. Bol Cient Pediatr. 2012; 01(1):29-35.

2. Goldstein B, Giroir B, Randolph A; International Consensus Conference on Pediatric Sepsis. International pediatric sepsis consensus conference: 
definitions for sepsis and organ dysfunction in pediatrics. Pediatr Crit Care Med. 2005; 6(1):2-8.

3. Dellinger PR, Levy MM, Rhodes A, Annane D, Gerlach H, Opal SM, et al. Campanha de sobrevivência à sepse: Diretrizes internacionais para tratamento de sepse grave e choque séptico: 2012. Crib Care Med. 2013; 41(2):580-637.

4. Chopra IJ. Clinical review 86: euthyroid sick syndrome: is it a misnomer? J Clin Endocrinol Metab.1997; 82(2):329-34.

5. De Groot LJ. Dangerous dogmas in medicine: the nonthyroidal illness syndrome. J Clin Endrocrinol Metab. 1999; 84(1):151-64.

6. Papanicolaou DA. Euthyroid sick syndrome and the role of cytokines. Rev Endocr Metab Disord. 2000; 1(1-2):43-8.

7. Economiedou F, Douka E, Tzanela M, Nanas S, Kotanidou A. Thyroid function during critical illness. Hormones (Athens). 2011; 10(2):117-24.

8. Papi G, Corsello SM, Pontecorvi A. Clinical concepts on thyroid emergencies. Front Endocrinol (Lausanne). 2014; 5(102):1-11.

9. Peeters RP, Wouters PJ, Kaptein E, Van Toor H, VisserTJ, Van den Berghe GV. Reduced activation and increased inactivation of thyroid hormone in tissues of critically ill patients. J Clin Endocrinol Metab. 2003; 88(7):3202-11.

10. Peeters RP, Wouters PJ, Toor HV, Kaptein E, Visser TJ, Van den Berghe G. Serum 3,3',5'-triiodothyronine (rT3) and 3,5,3' -triiodothyronine/rT3 are prognostic markers in critically ill patients and are associated with postmortem tissue deiodinase activites. J Clinical Endocrin Metab. 2005; 90(8):4559-67.

11. Marks SD. Nonthyroidal illness syndrome in children. Endocrine. 2009; 36(3):355-67

12. Golombek SG. Nonthyroidal illness syndrome and euthyroid sick syndrome in intensive care patients. Semin Perinatol. 2008; 32(6):413-8.

13. Colombo AL, Guimarães T. Epidemiologia das infecções hematogênicas por Candida ssp. Rev Soc Bras Med Trop. 2003; 36(5):599-607.

14. Borges RM, Soares LR, Brito CS, Brito DVD, Abdallah VOS, Gontijo Filho PP. Fatores de risco associados à colonização por Candida spp em neonatos internados em uma Unidade de Terapia Intensiva neonatal brasileira. Rev Soc Bras Med Trop. 2009; 42(4); 431-5.

15. Steinbach WJ, Roilides E, Bernan D, Hoffman JA, Groll AH, Bin-Hussain I, et al.; International Pediatric Fungal Network. Results from a prospective, international, epidemiologic study of invasive candidiasis in children and neonates. Pediatr Infect Dis J. 2012; 31(12):1252-7.

16. Nucci M, Queiroz-Telles F, Alvarado-Matute T, Tiraboschi IN, Cortes J, Zurita J, et al.; Latin American Invasive Mycosis Network. Epidemiology of candidemia in Latin America: a laboratory-based survey. PLoS One 2013; 8(3):e59373.

17. Roilides E, Farmaki F,Evdoridou J, Dotis J, Hatziionnids F, Tsivitanidou M, et al. Neonatal candidiasis: analysis of epidemiology; drug susceptibility, and molecular typing of causative isolates. Eur Eur J Clin Microbiol Infect Dis. 2004; 23(10):745-50.

18. Colombo AL, Nucci M, Park BJ, Nouér SA, Arthington-Skaggs B, Matta DA, et al.; Brazilian Network Candidemia Study. Epidemiology of candidemia in Brazil: a nationwide sentinel surveillance of candidemia in eleven medical centers. J Clin Microbiol. 2006; 44(8):2816-23.

19. Fisher DA. Euthyroid low thyroxine (T4) and triiodotyronine (T3) states in prematures and sick neonates. Pediatr Clin North Am. 1990; 37(6):1297-312.

20. De Zegher F, Vanhole C, Van Den Berghe G, Devlieger H, Eggermont E, Veldhuis JD. Properties of thyroid-stimulating hormone and cortisol secretion by the human newborn on the day of birth. J Clin Endocrinol Metab. 1994; $79(2): 576-81$
21. Das BK, Agarwal P, Agarwal JK, Mishra OP. Serum cortisol and thyroid hormone levels in neonates with sepsis. Indian J Pediatr. 2002; 69(8):663-5.

22. Moura EG, Moura CCP. Regulação da síntese e secreção de tireotrofina. Arq Bras Endocrinol Metab. 2004; 48(1):40-52.

23. Kaptein EM, Spencer CA, Kamiel MB, Nicoloff JT. Prolonged dopamine administration and thyroid hormone economy in normal and critically ill subjects. J Clin Endocrinol Metab. 1980; 51(2):387-93.

24. Van Den Berghe G, De Zegher, Lauwers P. Dopamine suppresses pituitary function in infants and children. Critic Care Med. 1994; 22(11):1747-53.

25. Langton JE, Brent GA. Nonthyroidal illness syndrome: evaluation of thyroid function in sick patients. Endocrinol Metab Clin North Am. 2002; 31(1):159-72.

26. Goldsmit GS, Valdes M, Herzovich V, Rodriguez S, Chaler E, Golombek SG, et al. Evaluation and clinical application of changes in thyroid hormone and TSH levels in critically ill full-term newborns. J Perinat Med. 2011; 39(1):59-64.

27. Yildizdaş D, Önenli-Mungan N, Yapicioğlu H, Topaloğlu AK, Sterdemir Y, Yüksel B. Thyroid hormone levels and their relationship to survival in children with bacterial sepsis and septic shock. J Pediatric Endocrinol Metab. 2004; 17(10):1435-42.

28. Dilli D, Dilmen S. The role of interleukin 6 and $C$ reactive protein in nonthyroidal illness in premature infants followed in neonatal intensive care unit. J Clin Res Pediatr Endocrinol. 2012; 4(2):66-71.

29. Lacour AG, Gervaix A, Zamora SA, Vadas L, Lombard PR, Dayer JM, et al. Procalcitonin, IL6, IL8, IL1 receptor antagonist and c reactive protein as identificators of serious bacterial infections in children with fever without localising signs. Eur J Pediatr. 2001; 160(2):95-100.

30. Matsumoto FE, Gandra RF, Ruiz LS, Auler ME, Marques SA, Pires MF, et al. Yeasts isolated from blood and catheter in children from a public hospital of São Paulo, Brazil. Mycopathologia. 2002; 154(2):63-9.

31. Reisner BS, Woods GL. Times to detection of bacteria and yeasts in bactec 9240 blood culture bottles. J Clin Microbiol. 1999; 37(6):2024-6.

32. Colombo AL, Nucci M, Salomão R, Branchini MLM, Ritchmann R, Derossi A, et al. High rate of non-albicans candidemia in Brazilian terciary care hospitals. Diagn Microbiology Infect Dis. 1999; 34(4):281-6.

33. Matta DA, Almeida LP, Machado AM, Azevedo AC, Kusano EJU, Travassos NF, et al. Antifungal susceptibility of 1000 Candida bloodstream isolates to 5 antifungal drugs: results of a multicenter study conducted in São Paulo, Brazil, 1995-2003. Diagn Microbiol Infect Dis.2007; 57(4):399-404.

34. Gondim BA, Brito DVN, Brito CS, Dolinger EJO, Abdallah VOS, Gontijo Filho PP. Fatores de risco para colonização e sepse por Candida albicans e Candida nao albicans em neonatos críticos. Arq Ciênc Saúde. 2009;16(3):105-9.

35. Zaoutis TE, Argon J, Chu J, Berlin JA, Walsh TJ, Feudtner C. The epidemiology and attributable outocmes of candidemia in adults and children hospitalized in the United States: a propensity analysis. Clin Infect Dis. 2005; 41(9):1232-9.

36. Rodriguez D, Almirante B, Park BJ, Cuenca-Estrella M, Planes AM, Sanchez F, et al.; Barcelona Candidemia Project Study Group. Candidemia in neonatal intensive care units: Barcelona, Spain. Pediatr Infect Dis J. 2006; 25(3):224-9.

37. Pereira CAP. Marra AR, Camargo LFA, Pignatari ACC, Sukiennik, Behar PRP, et al.; Brazilian SCOPE Study Group. Nosocomial bloosdtream infections in Brazilian pediatric patients: microbiolgy, epidemiology, and clinical features. PLoS One. 2013; 8(7):e68144 